\title{
POLITIK HUKUM PEMERINTAHAN DESA
}

\author{
Dodi Jaya Wardana, S.H., M.H. ${ }^{1}$ \\ Fakultas Hukum Universitas Muhammadiyah Gresik \\ dodijayawardana@umg.ac.id
}

\begin{abstract}
Abstarct
The State recognizes and respects regional government units that are special or special in nature which are regulated by law. Second, the State recognizes indigenous and tribal peoples' units along with their traditional rights insofar as they are alive and in accordance with the development of society and the principles of the Unitary State of the Republic of Indonesia, which are regulated in law. Politics of village government law, it cannot be separated from 3 (three) main bases, namely philosophical, sociological and juridical basis. The politics of regulatory law above are the basis for legal politics for regulations that are below, so that there should not be any universal inconsistencies. In addition, horizontally the legal politics of legislation must also be consistent.
\end{abstract}

\section{Keywords: Politics, Village and Government Laws.}

\section{Latar Belakang Masalah}

Indonesia merupakan Negara Kesatuan, yang Berbentuk Republik yang memiliki beribu-ribu pulau dari Sabang sampai Merauke. Dalam pulau-pulau tersebut terdapat desa, desa merupakan bagian dari Negara Kesatuan Republik Indonesia yang memiliki Pemerintahan dan otonomi sendiri. Karena itu, Pasal 18 Undang-Undang Dasar Negara Republik Indonesia Tahun 1945 antara lain menyatakan bahwa pembagian Daerah Indonesia atas daerah besar dan kecil dengan bentuk dan susunan pemerintahannya ditetapkan dengan undang-undang.

Desa atau yang disebut dengan nama lain telah ada sebelum Negara Kesatuan Republik Indonesia terbentuk. Sebagai bukti keberadaannya, Penjelasan Pasal 18 UndangUndang Dasar Negara Republik Indonesia Tahun 1945 (sebelum perubahan) menyebutkan bahwa "Dalam territori Negara Indonesia terdapat lebih kurang 250 "Zelfbesturende landschappen" dan "Volksgemeenschappen", seperti desa di Jawa dan Bali, Nagari di

\footnotetext{
${ }^{1}$ Dosen pada Fakultas Hukum Universitas Muhammadiyah Gresik
} 
Minangkabau, dusun dan marga di Palembang, dan sebagainya. Daerah-daerah itu mempunyai susunan Asli dan oleh karenanya dapat dianggap sebagai daerah yang bersifat istimewa. Negara Republik Indonesia menghormati kedudukan daerah-daerah istimewa tersebut dan segala peraturan negara yang mengenai daerah-daerah itu akan mengingati hakhak asal usul daerah tersebut". Oleh sebab itu, keberadaannya wajib tetap diakui dan diberikan jaminan keberlangsungan hidupnya dalam Negara Kesatuan Republik Indonesia. ${ }^{2}$

Keberagaman karakteristik dan jenis Desa, atau yang disebut dengan nama lain, tidak menjadi penghalang bagi para pendiri bangsa (founding fathers) ini untuk menjatuhkan pilihannya pada bentuk negara kesatuan. Meskipun disadari bahwa dalam suatu negara kesatuan perlu terdapat homogenitas, tetapi Negara Kesatuan Republik Indonesia tetap memberikan pengakuan dan jaminan terhadap keberadaan kesatuan masyarakat hukum dan kesatuan masyarakat hukum adat beserta hak tradisionalnya. ${ }^{3}$

Keberadaan desa jika dilihat berdasarkan pada perspektif sosiologis dan yuridis pada hakekatnya merupakan bentuk pemerintahan yang riil, demokratis, otonom dengan tradisi, adat istiadat dan hukumnyasendiri yang mengakar sangat kuat, serta relatif mandiri dari pengaruh entitas kekuasaan dari luar. Peraturan perundang-undangan yang mengatur desa selama ini menunjukkan inkosistensi dan ketidaksesuaian antara UUD NRI Tahun 1945 dengan UU organiknya, baik pada tataran asas, konsep maupun hirarkinya. ${ }^{4}$

Implikasi berubah-ubahnya politik hukum pemerintahan desa sebagaimana yang telah di sebutkan di atas berakibat pada hancurnya kehidupan politik, hukum, ekonomi dan sosial budaya di desa. Secara empirik dalam politik nampak hilangnya basis sosial seperti pranata sosial, kepemimpinan dan lembaga-lembaga adat. Dalam bidang hukum, konsep penguasaan negara atas bumi, air dan kekayaan alam yang terkandung di dalamnya, dalam implementasinya telah menjadi alat untuk menghilangkan kedaulatan masyarakat adat atas sumberdaya alamnya. Bidang ekonomi, nampak dari sumber daya alam masyarakat adat telah menjadi objek pemerintah dan pemodal swasta untuk mendirikan proyek-proyek besar. Sementara itu dari pandangan bidang sosial-budaya, yaitu dihilangkannya berbagai pengetahuan dan kearifan lokal milik masyarakat adat. ${ }^{5}$

\footnotetext{
${ }^{2}$ Lihat penjelasan Undang-Undang Nomor 6 Tahun 2014 Tentang Desa.

${ }^{3}$ Ibid

${ }^{4}$ Didik Sukriono, Hukum Konstitusi Dan Kajian Otonomi, Kajian Politik Hukum Tentang Konstitusi, Otonomi Daerah Dan Desa Pasca Perubahan Konstitusi. Malang:Setara Press, 2013, h. 173.

${ }^{5}$ Ibid., h. 174.
} 


\section{Rumusan Masalah}

Berdasarkan latar belakang masalah di atas, dapat dirumuskan rumusan masalah sebagai berikut:

1. Landasan filosofis, yuridis, dan sosiologis politik hukum pemerintahan desa setelah perubahan UUD NRI 1945 ?

2. Arah politik hukum pemerintahan desa yang di cita-citakan?

\section{Analisa dan Pembahasan}

\section{A. Landasan Filosofis, Yuridis, dan Sosiologis Politik Hukum Pemerintahan Desa}

Undang-Undang Dasar Negara Republik Indonesia Tahun 1945 menegaskan bahwa negara Indonesia adalah negara kesatuan yang berbentuk republik. Ditegaskan pula Indonesia adalah negara hukum yang berkedaulatan rakyat. Maknanya negara Indonesia adalah negara yang berdasarkan konstitusi, bersendikan demokrasi, dan berbentuk republik ${ }^{6}$ berdasarkan hukum (rechstaat) bukan berdasarkan kekuasaan belaka (manstaat). ${ }^{7}$

Namun mengingat wilayah negara Indonesia sangat besar dengan rentang geografi yang luas dan kondisi sosial-budaya yang beragam, UUD NRI 1945 kemudian mengatur perlunya pemerintahan daerah. Filosofi politik hukum pemerintahan desa, dapat dilihat berdasarkan pada ketentuan Pasal 18 UUD NRI 1945 sebelum perubahan yang berisikan "pembagian atas daerah yang ada di Indonesia ke dalam daerah yang besar dan kecil, dimana susunan dan bentuk pemerintahannya ditetapkan oleh undang-undang dengan menimbang dan mengingat dasar permustawaratan dalam sistem pemerintahan negara, dan hak asal-usul dalam daerah yang bersifat istimewa”. Hal demikian yang menjadikan kehendak dilahirkannya atau diadakannya otonomi daerah dan daerah otonom, dimana daerah bersifat otonom berdasarkan asas desentralisasi. Otonomi daerah menjadi sarana dalam mewujudkan proses pendemokratisasian pemerintahan hingga ke daerah-daerah. Hal demikian juga yang mendasari politik hukum pemerintahn daerah.

Lain halnya dengan filosofi politik hukum pemerintahan desa sesudah Perubahan UUD NRI dapat dilihat dari ketentuan Pasal 18B UUD NRI 1945, yaitu:

\footnotetext{
${ }^{6}$ Ibid., h. 176

${ }^{7}$ Kalimat yang bergaris bawah dari penulis sendiri.
} 
Pertama, Negara mengakui dan menghormati satuan-satuan pemerintahan daerah yang bersifat khusus atau bersifat istimewa yang diatur dengan undang-undang. Kedua, Negara mengakui kesatuan-kesatuan masyarakat hukum adat beserta hak-hak tradisionalnya sepanjang masih hidup dan sesui dengan perkembangan masyarakat dan prinsip Negara Kesatuan Republik Indonesia, yang diatur dalam undang-undang.

Berdasarkan pada bunyi Pasal 18B di atas, maka terlihat cita hukum yang diinginkan oleh otonomi daerah yaitu: (1). Pengakuan dan penghormatan terhadap satuan-satuan pemerintah daerah yang bersifat khusus atau bersifat istimewa; (2). Pengakuan dan penghormatan terhadap satuan-satuan pemerintahan daerah yang bersifat khusus atau bersifat istimewa diatur dengan undang-undang; dan (3). Negara mengakui dan menghormati kesatuan-kesatuan masyarakat hukum adat beserta hakhak tradisionalnya dengan sebuah persyaratan, yaitu sepanjang masih hidup dan sesuai dengan perkembangan masyarakat dan prinsip NKRI yang diatur dalam undang-undang.

Pada tataran undang-undang, secara kronologis nampak sebagai berikut: (a) UU No. 1 Tahun 1945 merupakan peraturan desentralisasi pertama dan menempatkan desa sebagai letak otonomi terbawah serta sebagai kesatuan masyarakat yang berhak mengatur rumah tangga pemerintahannya sendiri (self governing community); (b) UU No. 22 Tahun 1948, memberikan pengakuan dan perlindungan terhadap eksistensi desa sebagai kesatuan masyarakat yang memiliki asasl-usul dan berhak mengatur dan mengurus pemerintahannya sendiri dan mengarahkan desa, negeri, marga dan sebagainya menjadi daerah otonom tingkat III; (c) UU No. 1 Tahun 1957, filosopinya membagi daerah otonom menjadi dua jenis, yaitu daerah otonom biasa dan daerah swaparaja dan mengusung filosofi keberagaman; (d) UU No. 19 Tahun 1965, filosofinya mengusung semangat penyeragaman dan pembentukan daerah tingkat III; (e) UU No. 5 Tahun 1979, filosofinya menyeragamkan nama, bentuk, susunan dan kedudukan pemerintahan desa; (f) UU No. 22 Tahun 1999, filosofinya mengedepankan semangat pengaturan desa dari tingkat nasional menuju ke tingkat daerah dan dari birokrasi menjadi institusi masyarakat lokal. ${ }^{8}$

Semangat dasar UU No. 22 Tahun 1999 adalah memberikan pengakuan terhadap keragaman dan keunikan desa sebagai self-governing community sebagai manifestasi terhadap makna "istimewa” dalam Pasal 18 UUD NRI Tahun 1945; (g)

\footnotetext{
8 Ibid., h. 178
} 
UU No. 32 Tahun 2004, filosofinya melokalisir desa sebagai subyek hukum yang mengelola kepentingan masyarakat setempat, bukan urusan atau kewenangan pemerintahan, seperti halnya daerah. Negara hanya mengakui keberadaan desa, tetapi tidak membagi kekuasaan pemerintahan kepada desa. Desa hanya diakui sebagai kesatuan masyarakat hukum berdasarkan asal-usul dan adat-istiadat, bukan disiapkan sebagai entitas otonom sebagai local self government.

Lain halnya dengan keberadaan UU No. 6 Tahun 2014 Tentang desa filosofinya lebih kepada penguatan posisi desa. Desa telah berkembang dalam berbagai bentuk sehingga perlu dilindungi dan diberdayakan agar menjadi kuat, maju, mandiri, dan demokratis sehingga dapat menciptakan landasan yang kuat dalam melaksanakan pemerintahan dan pembangunan menuju masyarakat yang adil, makmur, dan sejahtera. ${ }^{9}$ Undang-Undang Desa disusun dengan semangat penerapan amanat konstitusi, yaitu pengaturan masyarakat hukum adat sesuai dengan ketentuan Pasal 18B ayat (2) untuk diatur dalam susunan pemerintahan sesuai dengan ketentuan Pasal 18 ayat (7). Walaupun demikian, kewenangan kesatuan masyarakat hukum adat mengenai pengaturan hak ulayat merujuk pada ketentuan peraturan perundangundangan sektoral yang berkaitan. ${ }^{10}$

Dengan konstruksi menggabungkan fungsi self-governing community dengan local self government, diharapkan kesatuan masyarakat hukum adat yang selama ini merupakan bagian dari wilayah Desa, ditata sedemikian rupa menjadi Desa dan Desa Adat. Desa dan Desa Adat pada dasarnya melakukan tugas yang hampir sama. Sedangkan perbedaannya hanyalah dalam pelaksanaan hak asal-usul, terutama menyangkut pelestarian sosial Desa Adat, pengaturan dan pengurusan wilayah adat, sidang perdamaian adat, pemeliharaan ketenteraman dan ketertiban bagi masyarakat hukum adat, serta pengaturan pelaksanaan pemerintahan berdasarkan susunan asli. Terakhir UU Nomor 23 Tahun 2014 Tentang Pemerintahan Daerah. UU ini merupakan aturan mengenai pemerintahan daerah yang terbaru, filosofinya dalam pengaturan desa hanya sebatas pada dimasukkannya desa ke dalam bagian dari kabupaten/kota. Lebih lanjut, secara yuridis, inti ketentuan Pasal 18 UUD NRI 1945 adalah dalam negara Indonesia terdapat pemerintahan daerah. Pemerintahan daerah tersebut terdiri atas daerah besar dan daerah kecil. Pemerintah daerah yang dibentuk

\footnotetext{
${ }^{9}$ Konsideran Menimbang Undang-Undang Nomor 6 Tahun 2014 tentang Desa

${ }^{10}$ Lihat penjelasan Undang-Undang Nomor 6 Tahun 2014 Tentang Desa.
} 
tersebut baik dalam daerah besar maupun daerah kecil harus memperhatikan dua hal yaitu: dasar permusyawaratan dan hak asal usul dalam daerah yang bersifat istimewa.

Eksistensi dari peranan desa yang sangat vital dalam kehidupan ketatanegaraan Republik Indonesia, telah disadari sejak the founding fathers dalam menyusun konstitusi Republik Indonesia. Secara tegas Soepomo pernah menyatakan perlunya menggunakan desa sebagai model dalam menyusun sistem pemerintahan Republik Indonesia, karena pemimpin harus bisa bersatu jiwa dengan rakyatnya seperti dalam tradisi pemerintahan desa pada masa itu. Dengan demikian Soepomo juga menghendaki diakuinya otonomi desa dalam sistem ketatanegaraan Republik Indonesia.

\section{B. Arah Politik Hukum Pemerintahan Desa yang Di Cita-Citakan}

Pembahasan mengenai politik hukum pemerintahan desa, maka tidak lepas dari 3 (tiga) landasan utama yaitu landasan filosofis, sosiologis dan yuridis. secara filosofis desa merupakan organisasi komunitas lokal yang mempunyai batas-batas wilayah, dihuni oleh sejumlah penduduk, dan mempunyai adat-istiadat untuk mengelola dirinya sendiri. ${ }^{11}$ Desa yang mempunyai pemerintahan sendiri dan dikelola secara otonom tanpa ikatan hirarkhis-struktural dengan struktur yang lebih tinggi, telah ada terlebih dahulu sebelum adanya negara. Dengan demikian desa yang memiliki tata pemerintahan lebih tua, seharusnya juga menjadi ujung tombak dalam setiap penyelenggaraan urusan pemerintahan, pembangunan dan kemasyarakatan.

Secara yuridis Undan g-undang Dasar 1945, Pasal 18 B mengamanatkan adanya kesatuan masyarakat hukum adat. Kemudian dalam penjelasan umum Undang-Undang No. 32 Tahun 2004 tentang Pemerintahan Daerah dijelaskan bahwa otonomi Desa akan diberikan kesempatan untuk tumbuh dan berkembang mengikuti perkembangan dari Desa itu sendiri. Hal ini berarti bahwa Desa sebagai susunan pemerintahan terendah di Indonesia mempunyai identitas dan entitas yang berbeda dan perlu di atur tersendiri dalam bentuk Undang-Undang. Ketentuan Pasal 18 UUD 1945 yang berbunyi: Pembagian daerah Indonesia atas daerah besar dan kecil, dengan bentuk susunan pemerintahannya di tetapkan dengan undang-undang, dengan memandang dan me ngingati dasar permusyawaratan dalam sistem pemerintahan

\footnotetext{
${ }^{11}$ Didik Sukriono, Hukum Konstitusi Dan. 
negara, dan hak-hak asal-usul dalam daerah-daerah yang bersifat istimewa. Ini berarti bahwa daerah yang lebih kecil mencakup kabupaten/kota dan Desa, atau setidaknya undang-undang juga harus memberi kedudukan yang tepat keberadaan Desa yang telah ada jauh sebelum NKRI lahir, dan Desa pada masa kolonial juga telah diatur tersendiri. $^{12}$

Secara sosiologis sebagian besar penduduk Indonesia berada di Desa dan hampir segala aspek menunjukkan betapa lemahnya kedudukan Desa dalam konstelasi pemerintahan. Artinya berbicara Desa berbicara tentang nasib sebagian besar rakyat Indonesia. Tetapi selama ini, pernbangunan cenderung berorientasi pada pertumbuhan dan bias Kota. Sumber daya ekonomi yang tumbuh di kawasan Desa diambil oleh kekuatan yang lebih besar, sehingga Desa kehabisan sumberdaya dan menimbulkan arus urbanisasi penduduk Desa ke kota. Kondisi ini yang menciptakan ketidakadilan, kemiskinan maupun keterbelakangan pada Desa. ${ }^{13}$ Dengan demikian diperlukan pembangunan tata hukum yang berkesinambungan dan berkeadilan bagi masyarakat, khususnya masyarakat desa.

Upaya pembangunan tata hukum yang terus menerus diperlukan agar hukum dapat memainkan peran dan fungsinya sebagai pedoman bertingkah laku dalam hidup bersama. Upaya tersebut dilakukan dengan alasan antara lain hukum harus senantiasa disesuaikan dengan perkembangan masyarakat yang dilayaninya, hukum sebagai alat pendorong kemajuan masyarakat, dan secara realistis adanya manipulasi terhadap hukum itu sendiri sebagai alat untuk menimbun kekuasaan.

Upaya pembaharuan tatanan hukum itu haruslah tetap menjadikan Pancasila sebagai paradigmanya, dapat menyentuh konstitusi atau Undang-Undang Dasar Negara Republik Indonesia Tahun 1945 sebagai hukum dasar tertulis tertinggi, dan semua peraturan perundang-undangan yang ada di bawahnya, serta berpedoman pada Undang Undang Nomor 12 Tahun 2011 tentang Pembentukan Peraturan Perundangundangan sebagai pedoman bakunya.

Demikian juga upaya pembaharuan tatanan hukum tentang desa harus adanya konsistensi arah politik hukum baik secara vertikal maupun horisontal, secara vertikal artinya arah politik hukum yang ada dalam Pancasila dan UUDNRI Tahun 1945 harus menjadi pedoman bagi arah politik hukum dalam undang-undang dengan kata lain politik hukum secara ideal (yang ada dalam pembukaan UUDNRI Tahun 1945) akan

\footnotetext{
${ }^{12}$ R. Yando Zakaria, Merebut Negara, Lapera Pustaka Utama, Yogjakarta, 2004, hal. 148.

${ }^{13}$ Didik Sukriono, Hukum Konstitusi Dan............., Op.Cit., h. 183
} 
menjadi pijakan bagi politik hukum secara dasar (UUDNRI Tahun 1945), dan politik hukum secara dasar menjadi pijakan bagi politik hukum secara instrumental (UndangUndang). ${ }^{14}$ Sementara secara horisontal arah politik hukum yang ada dalam undangundang yang satu harus konsisten dengan arah politik hukum dalam undang-undang yang lain.

Arah politik hukum dalam undang-undang tentang desa kedepan harus dilakukan perubahan agar sesuai dengan arah politik hukum dalam konstitusi atau UUDNRI Tahun $1945^{15}$ diantaranya persyaratan bagi kepala desa yang menyangkut masalah syarat pendidikan, seharusnya minimal Sekolah Lanjutan Atas atau yang sederajat, agar konsisten dengan arah politik hukum yang secara ideal dalam Pembukaan UUDNRI Tahun 1945 yakni dengan tujuan mencerdaskan kehidupan bangsa, yang dijabarkan lebih lanjut dalam Pasal 31 ayat (2) UUDNRI Tahun 1945 yang memerintahkan kepada setiap warga negara wajib mengikuti pendidikan dasar yang telah dilaksanakan dalam kebijakan wajib belajar 12 tahun.

Wajib belajar menurut Undang Undang Nomor. 20 Tahun 2003 tentang Sistem Pendidikan Nasional adalah program pendidikan minimal yang harus diikuti oleh Warga Negara Indonesia atas tanggung jawab Pemerintah Pusat dan Pemerintah Daerah. Pelaksanaan wajib belajar 12 tahun merupakan keberlanjutan dari wajib belajar 9 tahun yang dicanangkan Pemerintah Pusat. ${ }^{16}$ Program wajib belajar 12 tahun merupakan kewajiban bagi setiap Warga Negara Indonesia yang telah tamat sekolah menengah pertama atau sederajat dengan batas usia 16 sampai 18 tahun untuk mengikuti pendidikan sekolah menengah atas atau sederajat sampai tamat.

Pendidikan adalah proses pembangunan potensi, kemampuan dan kapasitas manusia yang mudah dipengaruhi oleh kebiasaan kemudian disempurnakan dengan kebiasaan-kebiasaan yang baik, di dukung dengan alat (media) yang disusun sedemikian rupa, sehingga pendidikan dapat digunakan untuk menolong orang lain atau dirinya sendiri dalam mencapai tujuan-tujuan yang ditetapkan. Orang yang

${ }^{14}$ https://ejournal.undip.ac.id/index.php/mmh/article/view/8941/7262. Di akses pada tanggal 5 April 2019. Lihat juga Retno Saraswati, 2014, "Reorientasi Hukum Pemilukada yang Mensejahterakan Rakyatnya", Jurnal Dinamika Hukum, Vol.14 No. 2 Edisi Mei, Purwokerto, Fakultas Hukum Universitas Jenderal Soedirman, h. 365.

${ }^{15}$ Ibid

${ }^{16}$ Ibid. Lihat juga Sitta Aulia, 2013, "Desentralisasi Kebijakan Pendidikan (Studi tentang Pelaksanaan Wajib Belajar 12 Tahun di Kota Surabaya pada tingkat Pendidikan Menengah dan Kejuruan)”, Jurnal Politik Muda, Edisi 59 Edisi Januari, Surabaya, Development Team of Scientific Journal Universitas Airlangga, h. 210. 
berpendidikan lebih tinggi semakin mempunyai bekal ilmu untuk melihat secara kritis terhadap berbagai permasalahan dan akan mendaya gunakan potensinya.

Di sisi yang lain dari pertimbangan kemampuan, tentu orang yang berpendidikan lebih tinggi akan lebih memiliki kemampuan yang lebih dibandingkan dengan orang yang pendidikannya lebih rendah. Padahal seorang kepala desa diharapkan menjadi penggerak pembangunan desa, jika kepala desa memiliki kemampuan sebagai penggerak pembangunan desa tentu ini akan sangat mempercepat tujuan untuk mensejahterakan masyarakat desa, menjadi desa yang mandiri dan maju. Pembangunan desa dapat menjadi upaya yang sangat penting dalam pengentasan kemiskinan di desa.

Dari sudut pandang politik dan administrasi pemerintahan, desa dipahami sebagai suatu daerah kesatuan hukum dimana bertempat tinggal suatu masyarakat yang berkuasa (memiliki wewenang) mengadakan pemerintahan sendiri. Pengertian ini sangat menekankan adanya otonomi untuk membangun tata kehidupan desa bagi kepentingan penduduk. Namun harus disadari bahwa otonomi berbeda maknanya dengan kedaulatan, sebesar apapun tuntutan otonomi, tetaplah dalam kerangka NKRI, karena dalam prinsip negara kesatuan kedaulatan ke dalam maupun keluar di tangan pemerintah pusat.

Konsep otonomi desa sebenarnya adalah sebuah konsep yang dimaknai sebagai adanya kemampuan serta prakarsa masyarakat desa untuk dapat mengatur dan melaksanakan dinamika kehidupannya dengan didasarkan pada kemampuannya sendiri. Hal ini berarti bahwa intervensi dari luar desa sendiri sedapat mungkin untuk dihilangkan atau paling tidak dikurangi. Sedangkan sifat otonomi desa adalah merupakan otonomi murni, artinya keberadaan otonomi desa adalah merupakan sesuatu yang memang telah ada sejak desa itu mulai ada, dan bukan merupakan sebuah limpahan wewenang dari negara. Otonomi desa tersebut memberikan kesempatan bagi masyarakat desa untuk dapat menunjukkan eksistensinya melalui berbagai aktivitas dalam mengelola persoalan yang ada dalam masyarakat desanya sesuai dengan kondisi obyektif masyarakat.

Dalam penyusunan rancangan pembangunan desa, pemerintah desa wajib menyelenggarakan musyawarah perencanaan pembangunan desa yang melibatkan masyarakat desa, karena partisipasi masyarakat menjadi sangat penting agar perencanaan pembangunan sesuai dengan kebutuhan riil masyarakat desa. Salah satu tujuan otonomi adalah untuk meningkatkan partisipasi masyarakat dalam 
pengambilan keputusan yang mempengaruhi kehidupan mereka. Sistem di era reformasi yang harus berkembang adalah sistem dalam paradigma baru dengan pola kebijakan pembangunan bottom up. ${ }^{17}$ Manfaat partisipasi masyarakat dalam pembuatan kebijakan publik termasuk dalam perencanaan pembangunan desa yang nantinya dituangkan dalam peraturan desa antara lain untuk memberikan landasan yang lebih baik, memastikan adanya implementasi yang lebih efektif, meningkatkan kepercayaan warga masyarakat, dan efisiensi sumber daya. Dengan keleluasaan pemerintah desa dan masyarakat desa untuk merencanakan pembangunan desa, maka akan lebih mencapai sasaran demi terwujudnya desa yang maju dan mandiri, tahu mana yang menjadi prioritas dalam pembangunannya. Pembangunan tersebut dalam rangka penanggulangan kemiskinan, sehingga pembangunan sumber daya manusianya, infrastrukturnya, pemanfaatan sumberdaya alamnya, dan pengembangan potensi ekonomi rakyat (lokal) harus diutamakan. ${ }^{18}$

\section{Kesimpulan}

Berdasarkan pada uraian di atas, maka telah sampai pada kesimpulan yaitu:

1. Negara mengakui dan menghormati satuan-satuan pemerintahan daerah yang bersifat khusus atau bersifat istimewa yang diatur dengan undang-undang. Kedua, Negara mengakui kesatuan-kesatuan masyarakat hukum adat beserta hak-hak tradisionalnya sepanjang masih hidup dan sesui dengan perkembangan masyarakat dan prinsip Negara Kesatuan Republik Indonesia, yang diatur dalam undangundang.

2. Politik hukum pemerintahan desa, maka tidak lepas dari 3 (tiga) landasan utama yaitu landasan filosofis, sosiologis dan yuridis. Politik hukum peraturan yang berada di atas menjadi dasar bagi politik hukum bagi peraturan yang berada di bawah,sehingga tidak boleh ada inkonsistensi secaravertikal. Di samping itu secara horisontal politik hukum peraturan perundang-undangan juga harus konsisten.

17 Ibid. Lihat juga Ajar Triharso, 2010, "Pemikiran Tentang Pemberdayaan Masyarakat Desa dan Peranan Pendidikan Tinggi: Implementasi Kebijakan dari Pro Konglomerasi ke Pro UKM”, Jurnal Masyarakat Kebudayaan dan Politik, Vol. 22 No. 4 Edisi November, Surabaya, Universitas Airlangga, h. 10.

${ }^{18}$ Isharyanto, Andriana Grahani Firdausy, 2013, "Interaksi Politik dan Hukum Dalam Pembentukan Legislasi Daerah (Studi Terhadap Proses Penyusunan Peraturan Daerah Di Dewan Perwakilan Rakyat Daerah Kota Surakarta)", Jurnal Yustisia, Edisi 87 Tahun XXII Edisi September-Desember, Surakarta, Fakultas Hukum Universitas Sebelas Maret, h. 43. 


\section{Daftar Pustaka}

Ajar Triharso, 2010, "Pemikiran Tentang Pemberdayaan Masyarakat Desa dan Peranan Pendidikan Tinggi: Implementasi Kebijakan dari Pro Konglomerasi ke Pro UKM", Jurnal Masyarakat Kebudayaan dan Politik, Vol. 22 No. 4 Edisi November, Surabaya, Universitas Airlangga

Didik Sukriono, Hukum Konstitusi Dan Kajian Otonomi, Kajian Politik Hukum Tentang Konstitusi, Otonomi Daerah Dan Desa Pasca Perubahan Konstitusi. Malang:Setara Press, 2013.

Isharyanto, Andriana Grahani Firdausy, 2013, "Interaksi Politik dan Hukum Dalam Pembentukan Legislasi Daerah (Studi Terhadap Proses Penyusunan Peraturan Daerah Di Dewan Perwakilan Rakyat Daerah Kota Surakarta)", Jurnal Yustisia, Edisi 87 Tahun XXII Edisi September-Desember, Surakarta, Fakultas Hukum Universitas Sebelas Maret.

Sitta Aulia, 2013, "Desentralisasi Kebijakan Pendidikan (Studi tentang Pelaksanaan Wajib Belajar 12 Tahun di Kota Surabaya pada tingkat Pendidikan Menengah dan Kejuruan)", Jurnal Politik Muda, Edisi 59 Edisi Januari, Surabaya, Development Team of Scientific Journal Universitas Airlangga

Naskah Akademik Rancangan Undang-Undang Tentang Desa, Direktorat Pmerintahan Desa Dan Kelurahan, Dirjen Pemberdayaan Masyarakat Dan Desa, Depdagri, Jakarta, 2007

R. Yando Zakaria, Merebut Negara, Lapera Pustaka Utama, Yogjakarta, 2004

Retno Saraswati, 2014, "Reorientasi Hukum Pemilukada yang Mensejahterakan Rakyatnya", Jurnal Dinamika Hukum, Vol.14 No. 2 Edisi Mei, Purwokerto, Fakultas Hukum Universitas Jenderal Soedirman

https://ejournal.undip.ac.id/index.php/mmh/article/view/8941/7262 